Article

\title{
The People's Champ: Doug Ford and Neoliberal Right-Wing Populism in the 2018 Ontario Provincial Election
}

\author{
Brian Budd \\ Department of Political Science, University of Guelph, Guelph, N1G 2W1, Canada; E-Mail: buddb@uoguelph.ca
}

Submitted: 16 September 2019 | Accepted: 17 December 2019 | Published: 5 March 2020

\begin{abstract}
The 2018 Ontario provincial election marked a decisive shift in the political direction of Canada's most populous province. The election brought an end to the long reign of the Ontario Liberal Party (2003-2018), whose government devolved into a series of scandals that resulted in a third-place finish. The Liberal's defeat came at the hands of the Progressive Conservative Party led by former Toronto city councillor, Doug Ford. The Progressive Conservative's victory was propelled on the back of Ford's deeply populist campaign where he promised to reassert the interests of 'the people,' expel the influence of elites and special interests, and clean up government corruption. This campaign discourse led many political opponents and media pundits to accuse Ford of importing the nativist, xenophobic, and divisive rhetoric of other radical right-wing populist leaders. This article advances the argument that rather than representing the importation of 'Trumpism' or other types of radical right-wing populism, Ford's campaign is better understood within the tradition of Canadian populism defined by an overarching ideological commitment to neoliberalism. In appealing to voters, Ford avoided the nativist and xenophobic rhetoric of populist leaders in the United States and Western Europe, offering a conception of 'the people' using an economic and anti-cosmopolitan discourse centred upon middle class taxpayers. This article makes a contribution to both the literatures on Canadian elections and populism, demonstrating the lineage of Ford's ideological commitment to populism within recent Canadian electoral history, as well as Ford's place within the international genealogy of right-wing populism.
\end{abstract}

\section{Keywords}

Canada; neoliberalism; political leadership; populism; right-wing politics

\section{Issue}

This article is part of the issue "Leadership, Populism and Power" edited by Cristine de Clercy (Western University, Canada).

(C) 2020 by the author; licensee Cogitatio (Lisbon, Portugal). This article is licensed under a Creative Commons Attribution 4.0 International License (CC BY).

\section{Introduction}

In the wake of the 2016 United States Presidential Election, Canadian exceptionalism has enjoyed a healthy resurgence. As its neighbor to south became swept up in the rising global tide of right-wing populism, Canada returned to a more pluralistic and progressive style of politics under Liberal Prime Minister, Justin Trudeau. The country's renewed commitment to liberal pluralism led many political commentators to confidently conclude that far right ideologies and populist movements had little social or political currency in Canada (Adams, 2017; "Liberty moves north: Canada's example to the world", 2016). However, recent developments have heightened concern that, like other liberal democracies in the Western world, Canada too might be susceptible to the growth of far-right movements. These concerns came to a head in the 2018 Ontario provincial election, where right-wing populist leader, Doug Ford, won a majority government in Canada's most populous province. Ford's election is one of the few recent cases of successful populism in Canada, where a growing number of fringe leaders, parties and movements have adopted the discourses of populist leaders from other parts of the globe (Budd, 2019). Ford's brash and common-sense approach to politics drew comparison to Donald Trump and other radical right-wing populists, where Ford was accused of championing the same xenophobic, nativist, and authoritarian ideology (Kassam, 2018; Marche, 2018; Porter, 2018).

This article advances the arguments that rather than representing the importation of populist radical rightwing ideologies that have taken hold in other parts of 
the world, Ford's campaign is better understood within the tradition of Canadian right-wing populism defined by an overarching ideological commitment to neoliberalism. In campaigning to voters, Ford largely avoided the type of nativist and xenophobic rhetoric of populist leaders in the United States and Western Europe, and instead offered a conception of 'the people' using an economic and anti-cosmopolitan discourse centred upon middle class taxpayers and opposition to urban elites. This argument is advanced using a discursive definition of populism to analyze a range of campaign material produce by Ford and the Progressive Conservative Party of Ontario (PC) during the election. This article makes a contribution to both the literatures on Canadian elections and populist leadership, demonstrating the lineage of Ford's ideological commitment to populism within recent Canadian electoral history, as well as Ford's place within a broader international context of right-wing populism.

\section{Theoretical Framework: A Discursive-Genealogical Approach}

In order to place Doug Ford in comparative perspective with other right-wing leaders, I adopt a discursive-genealogical approach that combines elements of Mudde's (2007) thin-centred ideology approach with a discursive definition of populism. Mudde (2004, p. 543) approaches populism as an "ideology that considers society to be ultimately separated into two homogenous and antagonistic groups, 'the pure people' versus 'the corrupt elite,' and which argues that politics should be an expression of the volonté générale (general will) of the people." This minimal definition accounts for the various expressions of populism from around the globe that see populism become combined with other 'thicker' ideologies such as conservatism, liberalism, socialism, or nativism (Mudde \& Kaltwasser, 2011). Approaching populism as a thin-centred ideology acknowledges that there is no singular or pure form of populism, but rather sub-types distinguished based on the ideologies of different parties and leaders.

Broadly speaking, populism can be bifurcated between left and right-wing variants. However, there is a great deal of variation within these two general categories of populism as well. On the right, we can distinguish between what Mudde (2007) refers to as the "populist radical right" and the "nonradical populist right." The former category includes parties and leaders that share a common core ideology of nativism, authoritarianism, and populism. The nativism dimension refers to the combination of nationalism and xenophobia that tends to manifest itself in proposals to facilitate the realization of a homogenous nation-state, whereas the pillar of authoritarianism refers to the ideological belief in an ordered society secured through an emphasis on law and order and punitive moralism. The nonradical populist right is a more diverse group of actors comprising those who combine a core right-wing ideology with populism while eschewing the extreme ideological tenets of the radical populist right.

One sub-type within this grouping is neoliberal populism. The concept of neoliberal populism was first developed by Betz (1994), who used the term to categorize populist leaders and parties emerging in the late 1980 s and early 1990s. Neoliberal populism can be understood as the combination of a primary ideology of economic liberalism with populism, typically expressed in a promotion of free market economics, individual liberty, and a commitment to traditional family structures and private property. Neoliberal populism differs significantly from the populist radical right. Brubaker (2017) argues that we can understand ideological differences between sub-types of populism based on the intersection between vertical and horizontal dimensions of opposition. According to Brubaker (2017), populism rests on the social construction of a vertical dimension of opposition where 'the people' are pitted against some class of political, economic, and cultural elites. There is also a horizontal dimension comprised of an insider-outsider distinction between 'the people' and groups of 'others' constructed along racial, ethnic, economic, and cultural lines. Neoliberal populism can be understood within this framework as defining vertical and horizontal opposition in primarily economic terms. In this way, neoliberal populists stand out from the recent wave of radical right-wing populists. As Inglehart and Norris (2016) argue, the recent global wave of populism is reflective of a value shift where the traditional left-right economic cleavage that has defined party competition in post-war Western democracies has been displaced by a cultural continuum arranged between exclusionary populist values on one pole and liberal cosmopolitan values on the other. This new cultural continuum of values is what accounts for the recent surge of populism, where leaders and parties have abandoned or blended traditional economic ideologies in favour of a politics focused on cultural backlash. Neoliberal populists thus stand out from this broader realignment of values in that their ideology and policy agenda is defined by the traditional left-right divide while omitting the core features of other forms of populism defined by a commitment to nativism, xenophobia, and authoritarianism (de Lange \& Mügge, 2015; Inglehart \& Norris, 2016).

While useful in parsing apart ideological variants of leaders and parties, the prevalence of the thin-centred ideology conception of populism has also led critics to identify a number of inherent challenges and shortcomings. As both Aslanidis (2015) and Moffitt (2016) have highlighted, the ideological approach infers that we understand populism as a fixed attitude of a leader or party. In other words, a particular political party or leader is either populist or not. This inherent binary between populists and non-populists belies research findings noting periodic forays into populism among leaders and parties not typically thought to be populist. This is particularly prescient in the Canadian literature on populism, 
where a number of scholars have persuasively demonstrated the Harper government's periodic affinity for populist appeals (Kelly \& Puddister, 2017; Sawer \& Laycock, 2009; Snow \& Moffitt, 2012). The ideological approach has trouble accounting for these populist displays by non-populists, representing a significant incongruence between theory and empirical reality. Thus, the ideological approach provides an imprecise empirical explanation of populism by failing to account for its strategic use in discourse among a wide array of leaders beyond those with a coherent populist worldview.

In noting this issue with the thin-centred ideology approach, I adopt an alternative discursive approach that understands populism as a discursive frame by which political ideologies, grievances, and interests become packaged and expressed (Aslanidis, 2015; Bonikowski \& Gidron, 2016; de Vreese, Esser, Aalberg, Reinemann, \& Stanyer, 2018). In assuming this approach, I define populism as an anti-elite discourse that invokes "the supremacy of popular sovereignty to claim that corrupt elites are defrauding 'the People' of their rightful political authority" (Aslanidis, 2015, p. 96). Similar to the thin-centred ideology approach, this definition retains the antagonistic divide between 'the people' and the elites/political establishment. However, in approaching populism as a discourse, the site of inquiry shifts to a focus on the various types of speech acts offered by political leaders and parties. Like the ideological approach, this discursive definition of populism retains a degree of conceptual 'thinness' allowing for an accounting of the differences between various enactments of populism. More importantly for this article, this discursive approach is consistent with the identification of genealogical variants of populism based on ideology discussed above. As a flexible and modular discourse, populism can be deployed by a range of different actors with various ideological dispositions and policy agendas. It is with this strength in mind that I apply the discursive-genealogical approach to analyze and compare Doug Ford's 2018 electoral campaign against the global roster of right-wing populists.

\section{Canadian Electoral Politics and Right-Wing Populism}

A complete review of the history of right-wing populism in Canada dating back to Confederation is well beyond the scope of this article. However, it is possible to briefly summarize some of the general characteristics of Canadian populist movements, leaders, and parties. One of the most defining characteristics of Canadian populism is the influence of regional political cultures, identity issues, and grievances. Many of the most well-known and successful populist movements in Canada have been organized around regional/provincial interests where right-wing politicians and parties have positioned themselves as opponents of an unaccountable and out-oftouch federal government. This is especially true of movements that have developed in Western Canada, where an engrained sense of regional alienation has helped to fuel several highly successful populist movements and parties. There are numerous examples of these throughout history including the Social Credit Party that governed Alberta from 1935 to 1968, Saskatchewan's Progressive Conservative Party during the 1970 s and, perhaps most notably, the creation of the federal Reform Party in the late 1980s (Wiseman, 2006). These parties and their leaders have expressed to varying degrees an ideological commitment to asserting the interests of Western Canadians against the intrusive and undemocratic policies of the federal government. The exact nature of these articulations has evolved over time. During the mid20th century, right-wing Western Canadian populists focused their appeals on articulating the interests of small businesses and individual consumers whose purchasing power and economic wellbeing, they argued, had been curtailed by a cadre of Eastern-based financial interests, government planners, bureaucrats, and political parties (Laycock, 1990, p. 206). Leaders and parties during this period advocated for reforms to democratic institutions that would scale back the influence and power of Eastern financial interests and replace them with plebiscitarian forms of democracy that would allow 'the people' direct input into fiscal policy-making (Laycock, 1990, p. 234). These populist discourses evolved considerably beginning in the late 1970s, where a new wave of Western populist leaders and parties emerged sparked by the introduction of Pierre Trudeau's National Energy Program and mega-constitutional debates surrounding the accommodation of Quebec. This subsequent wave of Western populism - typified by Preston Manning and the Reform Party-helped to displace the Progressive Conservatives as the de facto federal party of the right in Canada while opposing proposals for asymmetrical federalism that would grant Quebec increased power and jurisdiction relative to other provinces. Populists during this period also targeted federal social programs and policies that they saw as unfairly benefitting special interests at the expensive of middle-class taxpayers and wealth producing provinces. A through line to earlier Western populist movements was continued support for direct democracy reforms such as the increased use of referenda, the creation of a triple-E senate, and the popular ratification of constitutional amendments.

While populism in Canada is most widely associated with Western Canada, an overlooked tradition of rightwing populism also exists in Eastern Canada. Here, populism has also taken on a regional flavor, with populist grievances taking root in the form of anti-Francophone sentiments. The two most notable examples of this are the New Brunswick Confederation of Regions Party (1989-2002) and the People's Alliance of New Brunswick (2010-present). The Eastern tradition of Canadian populism has been largely concentrated around efforts aimed at repealing official bilingualism mandating the dual use of English and French in federal and provincial public services. Populists in the East have sought to position themselves as the voice of English-speaking pop- 
ulations whose interests, they argued, have been sacrificed by establishment parties and politicians who have catered to francophone voters (Martin, 1995). Like their Western Canadian counterparts, the Eastern tradition of populism has also focused its efforts on promoting individual freedom and responsibility, rolling back the entitlements of special interests, and introducing marketbased alternatives to government services (Gordon \& Chouinard, 2019).

In being shaped primarily by regional and linguistic divides, populism in Canada has also been defined by the relative absence of radical positions on issues of culture and immigration. Instead, Canadian iterations of populism, especially at the federal level, have tended to gravitate toward neoliberal ideologies and discourses while largely eschewing the nativism and xenophobia that has characterized populist leaders and parties in other parts of the world. Canadian populist discourse has generally reflected the underlying tenets of neoliberal ideology where 'the people' have been defined using economic signifiers and elites criticized for mishandling and wasting public resources and tax dollars. The primary political agenda of Canadian populists has focused on scaling back the entitlements of the welfare state while advocating for reduced taxation and an enhanced private sector in Canadian society. Canadian populist discourse has repeatedly invoked the undue influence of special interests defined largely as "feminist lobby groups, native organizations, organized labour, multicultural, linguistic and ethnic groups, the management of most crown corporations and state agencies, and public sector unions" (Laycock, 1994, p. 217). As Laycock (1994) notes, the influence of these out-groups has largely been criticized through the ideological prism of neoliberalism, where their accommodation has been lambasted as producing political outcomes that unfairly skew the natural market-based distribution of social and economic resources while violating the inalienable principles of formal individual equality. While generally opposed to a generous immigration policy and official multiculturalism, populists in Canada have evolved to frame their opposition using the language of economics and fiscal restraint as oppose to appeals to ethnic identity or social concerns (Koning, 2019).

In Ontario, populism has been especially rare compared to other parts of Canada. However, when it has taken root, it has generally come in the form of neoliberal populism where the focus has been on reducing government expenditures through the elimination of social programming. Mike Harris' Progressive Conservative government of the mid-1990s is the most prominent example of right-wing populism at the provincial level in Ontario. Inspired by the success of Manning and the Reform Party at the federal level of politics, Harris helped to usher in what he and the party called 'the commonsense revolution.' Harris' government sought to capitalize on a growing sense of economic uncertainty connected to the influence of globalization and a corresponding de- cline in institutional confidence to push forward a neoliberal agenda focused on reducing the size and spending of the Ontario government and replacing it with free market reforms and greater personal responsibility (Woolstencroft, 1997). Apart from this brief flourish at the provincial level of politics, populism has also made its way into municipal politics in Ontario. The late Rob Ford-Doug Ford's brother-brought a similar neoliberal populist message to Toronto City Hall during his tenure as Mayor. Ford's appeals to Torontonians rested on a blending of austerity, anti-elitism, and anti-cosmopolitanism where he successfully rallied the support of voters in suburban wards of the city against supposedly left-leaning downtown elites (Thomas \& Tufts, 2016). In many ways Rob Ford's mayoral run mirrors broader national trends in right-wing populism in that he largely avoided overt appeals to nativist or anti-immigrant sentiments in the course of constructing an ethnically diverse coalition of support (Kiss, Perrella, \& Spicer, 2019; Silver, Taylor, \& Calderón-Figueroa, 2019).

While regionalism and neoliberalism have helped to shape Canadian populism away from radical ideologies, there has been a recent uptick in Canadian leaders and parties engaging with more xenophobic, nativist, and nationalist forms of populism. Recently, Canadian rightwing politicians such as Kellie Leitch and Maxime Bernier have launched political campaigns focused on gathering support around concerns over immigration, national heritage, and illiberal forms of cultural expression (Budd, 2019). The mainstreaming of these exclusionary populist appeals is connected to broader shifts in right-wing discourse both in Canada as well as internationally, where a growing number of populist leaders in Western democratic countries have successfully challenged the consensus around immigration and multiculturalism. In light of this, it is worth considering not only how Ford fits into the global context of right-wing populism, but also whether or not Ford represents a progression toward a more radical, nationalistic version of populism in Canada.

\section{Context: The 2018 Ontario Provincial Election}

The 42nd Ontario general election was notable on a number of fronts. Firstly, the election marked a significant moment of departure in the political direction of the province. Up until the PCs victory in June of 2018, the Ontario Liberal Party had enjoyed 15 years of consecutive rule in Ontario. This long period of governance led to the accumulation of high-profile public scandals and policy controversies that over time began to sow seeds of mistrust among the public toward the ethical integrity and managerial competency of the Liberals and their leaders. As a result, the resounding narrative of the 2018 election became one of change and which opposition party, the PCs or New Democratic Party (NDP), were best prepared to offer sound leadership and restore trust in government (Delacourt, 2018). Second, the election was notable in regard to the turmoil that occurred in its lead-up. 
In the months prior to the election, the PCs enjoyed a healthy lead in the polls as it appeared to be a foregone conclusion that their then leader, Patrick Brown, would become Ontario's next premier. However, Brown's bid for premier was derailed in January of 2018, when allegations of sexual misconduct levied by two women surfaced in the news media. While denying any wrongdoing, under widespread public scrutiny and internal pressure from party leadership, Brown resigned as PC leader on January 25th, 2018. Brown's resignation ignited an unexpected and highly competitive leadership election. Despite not having any previous experience in provincial or federal politics, former Toronto city councillor, Doug Ford, narrowly edged out runner-up and veteran Member of Provincial Parliament, Christine Elliott, on the third ballot to become the new leader of the PCs. Elliott lost the leadership contest to Ford despite receiving a larger share of the overall popular vote amongst PC members $(51.7 \%)$. Ford's victory came as a result of the complex election system used by the PCs which combines preferential ballots with equally weighted ridings. Under the system, each of Ontario's 124 electoral districts is worth up to 100 electoral points which are awarded to candidates based on the weighted percentage of votes they receive in a riding (Grenier, 2018). This formula helped Ford to victory as he was able to take a larger share of electoral points in ridings that he won versus the share taken in ridings won by Elliott.

With less than three months before the election, Ford's entry as leader drastically altered the PC's strategy and the overall discourse of their campaign. Ford successfully reshaped the PCs in his own image, restructuring the party's platform and appeals to voters using the language of populism. This shift was a far cry from the traditional political brand of the PCs in Ontario and the preferred messaging of Ford's most recent predecessor. While occupying ideological space to the right of the Liberals and NDP, the PCs have historically been a centre-right party that has avoided overt ideological commitments in favour of a pragmatic brand of economic managerialism and sound political leadership (Malloy, 2017). This traditional posturing was the one adopted by Patrick Brown, who had reoriented the party toward a centrist, immigrant-friendly image following the party's more hardline shift to the right under former leader, Tim Hudak (2009-2014). Inheriting the PC's lead in the polls following Brown's resignation, Ford pivoted the party away from this centrist orientation and initiated a fullscale adoption of populism. In his election platform, aptly titled A Plan for the People, Ford offered a suite of campaign promises intended to draw upon popular discontent with the political status quo. Included in Ford's platform were promises to repeal Ontario's cap and trade plan to reduce greenhouse gas emissions, fire the CEO of Ontario's utility provider Hydro One, scrap Ontario's revised sex-ed curriculum, and launch a full audit of government spending under the previous Liberal government (PC, 2018). These promises were framed as part of a broader effort by Ford to put 'the people' ahead of political elites who he accused of unfairly benefitting from government waste and mismanagement to the detriment of taxpayers. The PC's political opponents were attacked using the same type of populist discourse framed as corrupt political elites beholden to special interests.

Ford's populist agenda and discourse proved a successful pathway to electoral victory for the PCs. The party came away with a majority government winning 76 seats to the NDP's 40, the Liberal Party's seven and the Green Party's one. It is important to note that the PC's majority was supported by only $40.5 \%$ of the popular vote. This gap between the popular vote and the allocation of seats is a common outcome of Ontario's single-member plurality electoral system, where 7 of the last 8 elections held since 1990 have produced majority governments supported by less than $50 \%$ of the popular vote. Nevertheless, the election demonstrated the appeal of Ford's populist brand of politics among Ontarians, particularly those residing in non-urban regions of the province. Geographically, Ford found the strongest support in suburban and rural areas, taking most of the seats within the Greater Toronto Area and the rural regions located in the southern half of Ontario. Demographically, pre-election polling found that Ford's support tended to be strongest among younger voters with less education and lower incomes for whom economic pessimism is high and issues of immigration and globalization are considered important (EKOS Politics, 2018). This demographic concentration of support is consistent with support for other right-wing populists, which tends to be rooted in a growing sense of political disaffection, backlash against globalization, and an opposition to population migration (Norris, 2005).

Thus, it would appear that Ford's adherence to populism during the campaign and the profile of his support mirrors the rise of populists from other parts of the world. The similarities between Ford and other rightwing populist leaders, particularly Donald Trump, provoked a great deal of media commentary during the campaign while also serving as the basis of attack for his political opponents. Ford's brash, common-sense approach to politics and right-wing policy agenda left many media pundits to wonder if the 2018 Ontario provincial election marked Canada's very own "Trump moment" (Kassam, 2018). For political opponents, mostly Kathleen Wynne and the Liberal Party, branding Ford as a cheap imitation of Trump served as a key line of attack during the election in an effort to court voters supportive of the PCs but concerned with the importation of divisive rightwing populism (Powers, 2018). Ultimately, these unflattering comparisons fell short in preventing Ford from becoming premier. However, the similarities between Ford and other right-wing populists warrants further attention. How closely does Ford's ideology resemble other right-wing populists? The remainder of this article makes an effort to place Ford within the global context of rightwing populism. 


\section{Data and Methodology}

In analyzing the ideological elements of Ford's populist discourse, I follow the approach laid out by prominent discourse theorist, Teun van Dijk (1995). Van Dijk (1995, p. 17) argues that we understand ideology as:

The basic frameworks for organizing the social cognitions shared by members of social groups, organizations or institutions. In this respect, ideologies are both cognitive and social. They essentially function as the interface between the cognitive representations and processes underlying discourse and action, on the one hand, and the societal position and interests of social groups, on the other hand.

In other words, ideologies form both the interpretive schemata for individuals as well as the values, principles, and interests that bind social groups/collectives together. The task for analysis then is to understand how discourse, in the form of discrete speech acts, functions to persuasively convey ideological meaning to inform subjective and intersubjective worldviews. In the context of this article, I am interested in understanding the ideological composition of Ford's populist discourse and the degree it resembles the ideological worldviews of other populists.

The analysis I offer below is based on a discourse analysis of campaign material and public appearances offered by Ford during the official campaign period (May 9-June 7, 2018). Included in the analysis is the PCs official party platform, Ford's performance during 3 official leadership debates, as well as campaign videos produced by the PCs featuring Ford. In total, I have analyzed 40 videos posted on the Ford Nation Live website. The videos are shot in the style of news segments featuring a journalist reporting on a recent public appearance by Ford on the campaign trail, a gaffe or scandal involving another party, or a major policy announcement introduced by the PCs. The analysis of the videos focuses on both the discursive contours of speech as well as included imagery and visuals. As Moffitt's (2016) work argues, it is increasingly important that we focus on the visual self-presentation of populist leaders in light of the contemporary age of hyper-mediated and stylized politics. The videos produced by the PCs provide a window into the role of populist discourse during the campaign and pertinent material for assessing Ford's ideological orientation as expressed in appeals to Ontario voters.

\section{Research Findings}

\subsection{Defining the People: Taxpayers, Government Insiders, and Radical Special Interests}

Across the campaign material produced by Ford and the PCs, a very clear discursive construction of 'the people' emerges. While Ford's campaign slogan is literally "For the People," examining his discourse over the course of the campaign reveals that Ford's definition of 'the people' is confined to and structured around the signifiers of 'taxpayers' and the 'middle class.' For Ford, 'the people's' interests are those that belong to taxpaying citizens who under the Liberal government have been exploited by scandals involving government insiders and political elites. The oppositional framing between taxpayers and well-connected insiders is consistently used to frame Ford's policy agenda, especially his opposition to Ontario's cap and trade system and his proposals to terminate highly paid public servants (Ford Nation, 2018b, 2018h). Ford's championing of the taxpayers' interests represents the centre piece of his campaign that positions his prospective PC government as signalling an "end to the party with taxpayers' money" and the ushering in of a government that embraces fiscal restraint and curtails wasteful government spending (Ford Nation, 2018j). However, while Ford's discursive definition of 'the people' is rooted in class-based appeals, his populist discourse largely avoids direct references to working class Ontarians. Instead, Ford's definition of the middle class is confined to entrepreneurs and small business owners. This is exemplified in the videos released by Ford and the PC's announcing tax cuts for the middle class that are accompanied by interviews with CEOs, entrepreneurs and small business owners praising Ford's proposals and linking them to supporting average hardworking Ontarians (Ford Nation, 2018f, 2018g). In Ford's populist discourse, entrepreneurs become the embodiment of the middle class and ultimately the vanguard to middle class success, serving as job creators and wealth generators for 'the people.'

Equally important as who 'the people' are, is who 'the people' are not. Populist discourse hinges on the construction of an elite class whose power operates against the interests of 'the people.' Additionally, populists also focus their efforts on constructing an identifiable 'other' typically in the form of a competing social group that threatens 'the people' in some way. Ford's populist discourse includes consistent and clear elements of antielitism in the form of criticisms of the political establishment who he claims have been coopted by political elites and insiders that have used their special political connections to defraud taxpayers. The construction of elites in Ford's discourse emerges primarily out of attacks against the outgoing Liberal government, who he accuses of systemic corruption and using their authority to enrich their close friends and colleagues. Ford's crusade against political insiders is typified in his criticism of Hydro One's CEO who he labels "Kathleen Wynne's six million dollar man" (Ford Nation, 2018a). Issues involving Ontario's main utility provider have been long gestating, beginning with rapid increases in hydro rates under the Liberal government in the early 2000s. These issues were magnified following the Liberal government's decision in November of 2015 to privatize a portion of Hydro One in order to pay down provincial debt and fund transit projects. Ford juxtaposed these longstanding issues with the renumer- 
ation of its CEO and Board of Directors to reinforce the image of a political establishment designed to enrich the wealthy at the expense of the middle class. Ford successfully positioned himself as the only politician capable of expelling these unaccountable bureaucratic elites from power while promising to end the "Liberal practice of making millionaires from your hydro bills" (PC, 2018).

Ford's populism also prominently featured declarations against "radical special interests" who serve in the role of the 'other' in his discourse. The groups falling under the banner of special interests never receive a full articulation, however they are frequently linked to the NDP and their supporters. Ford largely frames these radical interests as being opposed to 'the people' based on their resistance to the creation of economic opportunities and individual prosperity for the middle class. The construction of special interests in Ford's discourse retains a distinct geographic dimension, as Ford positions special interests as being from "downtown Toronto" and motivated by a desire to eliminate economic opportunities for those residing in suburban and rural regions of the province (Ford Nation, 2018i). Radical special interests received particular attention during the Northern Leaders' Debate where Ford accused the NDP of harbouring candidates who would close mines and stifle the development of the forestry industry in Ontario's North. The evocation of urban-based radical interests by Ford echoes the anti-cosmopolitanism that characterized his brother's populism during his time as Mayor of Toronto (Silver et al., 2019; Thomas \& Tufts, 2016). Anti-cosmopolitanism played a similar role in Doug Ford's provincial campaign, where it became a discursive strategy to advance neoliberal reforms aiming to increase private sector productivity and eliminate government oversight, while strengthening Ford's appeal amongst suburban and rural voters.

\subsection{Performing Crisis: Government Corruption and the Promise of a Neoliberal Dawn}

The populism literature suggests that successful populists tend to capitalize on moments of political, social, or cultural crisis in order to appeal to 'the people' and justify the drastic measures outlined in their policy agendas (Taggart, 2000). As Moffitt (2016) rightly notes, while traditionally treated as an external trigger, crisis is best understood as an internal feature of populism that is rendered present through populist discourse and performance. In other words, crisis is something that is imagined and created by populist leaders and parties. In the case of Ford, the crisis that is brought to bear is primarily economic in nature. Ford's discourse is heavily structured around the identification of various institutional failures including scandals involving Hydro One, the size of the provincial debt, the impending economic damage of Ontario's cap and trade plan and lengthy hospital wait times. Importantly, Ford links these crises together as a symptom of a broader democratic deficit between politicians and 'the people.' As Ford outlines in his campaign platform: "The problems facing Ontario share one thing in common: Kathleen Wynne's Liberal government just doesn't care about you anymore" (PC, 2018). Ford and the PCs draw explicit ties between Liberal scandals, institutional failings and the unwillingness of establishment politicians to listen to or protect the interests of Ontarians. This linking of political crisis to democratic representation is a common strategy of populists writ large (Canovan, 1999). In Ford's version of populism, democratic representation becomes tied to the abuse and manipulation of taxpayers, whose freedom and prosperity are portrayed as being curtailed by unaccountable and out-of-touch elites.

Importantly, Ford adds a temporal dimension to his critique of the political establishment by framing the potential of electing an NDP government as exacerbating this crisis for taxpayers. During the campaign, Ford repeatedly argued that the NDP are like the Liberals except "10 times worse" while referencing the NDP government of the 1990s as evidence of what would happen if they were elected. The economic threat of the NDP is crystalized in the following statement given by Ford in a postdebate scrum:

I've talked to hundreds of small businesses. They are terrified, absolutely terrified about the NDP coming in. And you know what, you look back, back when they were back in power, they lost 125000 jobs in less than 4 years, unemployment skyrocketed $28 \%$ higher, welfare rates went up. (CBC News, 2018)

This use of the past points to a unique feature of Ford's populism. Taggart (2000) argues that populist rhetoric tends to rely on referential appeals to the past in the form of an imagined 'heartland' that serves as an idealized society structured around the inherent interests and shared values of 'the people.' For Ford, the past is not praised or positioned as a place to return to, but rather is an example of what has gone wrong in Ontario. Instead, Ford casts his populist gaze forward, projecting an idealized representation of Ontario as a land of unrestrained individual opportunity: "A new day will dawn: a day of prosperity, a day of growth, a day of opportunity this province has never seen before" (Ford Nation, 2018i). This imagined Ontario is consistent with Ford's broader neoliberal worldview, where the issues and challenges affecting Ontarians can be boiled down to a lack of individual economic freedom stemming from an inefficient, burdensome and bloated provincial government.

\subsection{For the Little Guy: Epistemological Appeals to Common-Sense and the Sovereignty of 'the People'}

A critical task for populist leaders is not just defining who 'the people' are, but also positioning themselves as speaking on their behalf (de Vreese et al., 2018). In other words, it is essential for populist leaders to assert 
themselves as the voice of 'the people' and the legitimate expression of the popular will. In Ford's discourse, we see this accomplished by epistemological appeals to common-sense and the linking of policy proposals to dialogue with citizens. The early portion of Ford's campaign was presented in the narrative of a bus tour with the goal of connecting with 'the people' and listening to their concerns. In a video updating Ford's campaign, the reporter featured in the video offers the following update: "Doug Ford is listening and gathering real information" while "connecting with people who are disconnected from Queens Park" (Ford Nation, 2018d). In another video highlighting Ford's attendance at cultural events, one of his supporters describes Ford as "not your typical ivory tower type, he cares about connecting with the people" (Ford Nation, 2018e). These discursive appeals to real, common-sense knowledge play an integral role in framing Ford's policy agenda while helping to sediment his connection with average middle-class Ontarians. His proposal to cut taxes and reduce waste are repeatedly framed as part of a broader effort to "put money back in the pocket of taxpayers" (Ford Nation, 2018d) under the logic that the people' know how to spend their money far better than any bureaucrat or politician. In sum, Ford's anti-government discourse and everyman self-presentation function to construct him as being intimately connected to and bringing expression to the voice of 'the people.'

Ford's positioning of himself as the expression of the popular will also relies on discursive opposition to other forms of knowledge. Ford's critique of the political establishment and government services evokes a repudiation of technocratic forms of knowledge and bureaucratic managerialism. This comes out most clearly in Ford's promise to end 'hallway healthcare' which served as a central plank of the PC's policy platform throughout the campaign. Ford repeatedly blames the issues facing Ontario's healthcare system on bureaucratic oversight arguing that "for common-sense Ontarians, we need less money lining the pockets of bureaucrats and more for hospital beds" (Ford Nation, 2018c). More importantly for Ford, politicians are called on to start listening to frontline healthcare workers and service providers to gain insight into how healthcare can be made more efficient and cost-effective. The PC's campaign communications outlining their plan for healthcare prominently feature interviews with nurses, doctors, and other service providers who provide firsthand accounts of issues in the healthcare system. These representations help to reinforce the anti-government and free market orientation of Ford's populism by challenging the wisdom of government planners and lionizing common-sense, experiential forms of knowledge.

\section{Discussion and Conclusion}

Doug Ford's 2018 election campaign provides a useful case study toward understanding both the histori- cal legacy and future potential of right-wing populism in Canada. In examining Ford's discourse, it is quite clear that his particular brand of populism eschews the ideological tenets that scholars have used to characterize the populist radical right. In campaigning to Ontarians, Ford largely avoided deploying xenophobic or nativist appeals to ethnic identity or nationalism. Rather, his discourse relied on a neoliberal conceptualization of 'the people' structured around economic signifiers focused on appealing to a shared sense of middle-class identity. In Ford's populist worldview, the issues and interests that matter are those that belong to middle-class taxpayers whose collective prosperity has been limited by inefficient bureaucrats and corrupt politicians. This populist vision of society not only provided the jumping off point for Ford to offer his own preferred set of neoliberal free market reforms but allowed him to construct an inclusive conception of 'the people' that cut across racial and ethnic lines. Thus, Ford's populism stands apart from other recent populist leaders who have ascended to power on the back of anxieties about social or cultural change. Rather, Ford can be understood as part of a broader historical lineage of Canadian right-wing populism, where ethnic, cultural, and social concerns have been marginalized in favour of a unified focus on formal political equality and market-based reforms to government programs (Farney, 2019; Farney \& Koop, 2017; Sawer \& Laycock, 2009). Ford's promotion of middle-class identity as a unifying signifier is firmly in line with this ideological lineage.

On a broader level, Ford's campaign demonstrates the contextually contingent nature of successful iterations of populism. The leveraging of neoliberal and anticosmopolitan appeals represents ideological tenets that have significant currency in the unique political context of Ontario where a large and ethnically diverse proportion of citizens reside in seat-rich suburban ridings. As mentioned, Ford's brother, Rob, rode similar populist themes to serve a tumultuous term as Mayor of Toronto, successfully mobilizing disenchantment toward downtown elites to create an ethnically diverse coalition of support among suburban voters (Kiss et al., 2019; Silver et al., 2019). This geographic divide between out-oftouch urban elites and ordinary people residing in suburbs played a key role in the PC's victory in 2018 as well. The coupling of neoliberal and anti-cosmopolitan discourses capable of transcending racial and ethnic divides sheds insight into the ways in which populism - at least electorally successful examples-conform to the specific social, cultural, and political contexts in which they unfurl (Budd, 2019; Moffitt, 2016). Ford's success in the 2018 election should also be understood as an outcome of the resonance of his neoliberal populist discourse within the unique political cultural of Ontario. While initially populated by Anglo-Celtic residents, successive waves of immigration since the 1950s have transformed Ontario into a highly diverse multicultural province with a political culture that privileges inclusiveness, fair treatment, and equality (Woolstencroft, 2016). However, Ontario's polit- 
ical culture has also maintained many of its 'red Tory' roots centred on a view of government as being responsible for fostering economic success and demonstrating managerial efficiency. Ford's non-exclusionary brand of neoliberal populism focused on free market managerialism has a natural symbiosis within this cultural and political context.

On the surface then, Ford's blending of neoliberal ideology and populist discourse distinguishes him from other right-wing populists. Moreover, the absence of xenophobia and nativism in Ford's appeals to Ontarians renders comparisons between Ford and other populists made during and after the election largely unsupported. The analysis offered in this article may serve as evidence to support the conclusion that Canada is immune to the wave of radical right-wing populism that has infiltrated other countries (Adams, 2017). However, while there is an absence of overt appeals to cultural and ethnic divisions, we should not assume that Ford's neoliberal populist discourse during the election is free of racialized elements. Rather, we might reasonably interpret the absence of explicit discursive appeals to cultural or ethnic signifiers as an outcome of the neoliberalization of multicultural discourse that has been crafted by right-wing politicians and parties in Canada over the last three decades. As Kwak (2019, p. 1709) notes, conservative politicians have engaged in a gradual process of "racial realignment" whereby right-wing policies and electoral platforms have been re-encoded with neoliberal signifiers as part of efforts to appeal to immigrant communities. This neoliberal reimaging of racial and ethnic difference has allowed right-wing leaders and parties to strengthen their appeal to non-white communities by demarcating these communities between ideal and non-ideal neoliberal subjects. The former are defined as those imbued with an entrepreneurial spirit and independence for whom ethnic and religious differences become muted through economic integration. The latter category has been branded with the label 'special interests' and deemed undesirable based on their lack of economic value and the unreasonable demands they direct toward the state for group-based accommodation (Kwak, 2018). Thus, the importance of 'special interests' within Ford's discourse is well in line with the broader evolution of right-wing political discourse in Canada whereby racial social hierarchies have become reinforced by seemingly neutral, inclusionary neoliberal subjectivities. It is important that future studies of populism in Canada and elsewhere consider these subtle and often covert neoliberal racial politics when analyzing and studying populist leaders.

\section{Acknowledgments}

I would like to extend my appreciation to J. P. Lewis and other attendees of the 2018 Atlantic Provinces Political Science Association Conference who offered feedback on an early draft of this article.

\section{Conflict of Interests}

The author declares no conflict of interests.

\section{References}

Adams, M. (2017). Could it happen here? Canada in the age of Trump and Brexit. Toronto: Simon and Schuster.

Aslanidis, P. (2015). Is populism an ideology? A refutation and a new perspective. Political Studies, 64(1), 88-104.

Betz, H. G. (1994). Radical right-wing populism in Western Europe. New York, NY: St. Martin's Press.

Bonikowski, B., \& Gidron, N. (2016). Multiple traditions in populism research: Toward a theoretical synthesis. APSA Comparative Politics Newsletter, 26(12), 7-14.

Brubaker, R. (2017). Why populism? Theory and Society, 46(5), 357-385.

Budd, B. (2019). The populist radical right goes Canadian: An analysis of Kellie Leitch's failed 2016-2017 Conservative Party of Canada leadership campaign. In F. A. Stengel, D. B. MacDonald, \& D. Nabers (Eds.), Populism and world politics: Exploring inter- and transnational dimensions (pp. 137-164). Cham: Palgrave Macmillan.

Canovan, M. (1999). Trust the people! Populism and the two faces of democracy. Political Studies, 47(1), 2-16.

CBC News. (2018, May 27). Ontario leaders' debate [Video file]. Retrieved from https://www.youtube. com/watch?v=LerC609m/3A

de Lange, S. L., \& Mügge, L. M. (2015). Gender and rightwing populism in the low countries: Ideological variations across parties and time. Patterns of Prejudice, 49(2), 61-80.

de Vreese, C. H., Esser, F., Aalberg, T., Reinemann, C., \& Stanyer, J. (2018). Populism as an expression of political communication content and style: A new perspective. The International Journal of Press/Politics, 23(4), 423-438.

Delacourt, S. (2018). What is it that is driving Ontario voters? The Toronto Star. Retrieved from https://www.thestar.com/opinion/star-columnists/ 2018/05/24/what-is-it-that-is-driving-ontariovoters.html

EKOS Politics. (2018). EKOS predicts PC majority. EKOS Politics. Retrieved from http://www.ekospolitics. com/index.php/2018/06/ekos-predicts-pc-majority

Farney, J. (2019). From Grant to Hayek: The shifting nature of Canadian conservatism. In D. McGrane \& N. Hibbert (Eds.), Applied political theory and Canadian politics (pp. 21-41). Toronto: University of Toronto Press.

Farney, J., \& Koop, R. (2017). The Conservative Party in opposition and in government. In J. P. Lewis \& J. Everitt (Eds.), The blueprint: Conservative parties and their impact on Canadian politics (pp. 25-45). 
Toronto: University of Toronto Press.

Ford Nation. (2018a, April 14). Cleaning up the hydro mess [Video file]. Retrieved from http://www. fordnationlive.ca/clean_up_the_ontario_hydro_ mess

Ford Nation. (2018b, April 19). BOMBSHELL: Hydro one executives vote themselves millions of dollars [Video file]. Retrieved from http://www.fordnationlive.ca/ bombshell_hydro_one_executives_vote_themselves _millions_of_dollars

Ford Nation. (2018c, April 20). Doug Ford's plan to reduce hospital wait times [Video file]. Retrieved from http://www.fordnationlive.ca/doug_ford_s_plan_ to_reduce_hospital_wait_times

Ford Nation. (2018d, April 21). RECAP: Week 1 of Doug Ford's campaign bus tour [Video file]. Retrieved from http://www.fordnationlive.ca/recap_week_1_ of_doug_ford_s_campaign_bus_tour

Ford Nation. (2018e, May 1). For the people: Doug Ford attends community events in Toronto and Vaughan [Video file]. Retrieved from http://www. fordnationlive.ca/for_the_people_doug_ford_ attends_community_events_in_toronto_and_vaughan

Ford Nation. (2018f, May 10). Tax cut for the middle class [Video file]. Retrieved from http://www. fordnationlive.ca/tax_cut_for_the_middle_class

Ford Nation. (2018g, May 14). Ontario is open for business! [Video file]. Retrieved from http://www. fordnationlive.ca/ontario_is_open_for_business2

Ford Nation. (2018h, May 18). Hydro scandal deepens [Video file]. Retrieved from http://www.ford nationlive.ca/hydro_scandal_deepens

Ford Nation. (2018i, May 23). Meet the real NDP [Video file]. Retrieved from http://www.fordnationlive.ca/ meet_the_real_ndp

Ford Nation. (2018j, May 26). Respect for taxpayers [Video file]. Retrieved from http://www. fordnationlive.ca/respect_for_taxpayers

Gordon, K., \& Chouinard, S. (2019). Anti-bilingual populism in Canada. Paper presented at the Canadian Political Science Annual Conference, Vancouver, Canada.

Grenier, E. (2018, March 11). Christine Elliott won more votes, but Doug Ford won where it mattered. $C B C$ News. Retrieved from https://www.cbc.ca/news/ politics/grenier-pc-leadership-results-1.4571699

Inglehart, R. F., \& Norris, P. (2016). Trump, Brexit, and the rise of populism: Economic have-nots and cultural backlash (HKS Faculty Research Working Paper Series RWP16-026). Cambridge, MA: Harvard Kennedy School.

Kassam, A. (2018, April 30). Canada's Trump moment? Doug Ford rises in conservative party. The Guardian. Retrieved from https://www.theguardian. com/world/2018/apr/30/doug-ford-ontarioconservative-trump-comparison-canada

Kelly, J. B., \& Puddister, K. (2017). Criminal justice policy during the Harper era: Private member's bills, penal populism, and the Criminal Code of Canada. Canadian Journal of Law \& Society, 32(3), 391-415.

Kiss, S. J., Perrella, A., \& Spicer, Z. (2019). Right-wing populism in a metropolis: Personal financial stress, conservative attitudes, and Rob Ford's Toronto. Journal of Urban Affairs. Advance online publication. https:// doi.org/10.1080/07352166.2019.1657021

Koning, E. A. (2019). Immigration and the politics of welfare exclusion: Selective solidarity in Western democracies. Toronto: University of Toronto Press.

Kwak, L. J. (2019). "New Canadians are new conservatives": Race, incorporation and achieving electoral success in multicultural Canada. Ethnic and Racial Studies, 42(10), 1708-1726.

Laycock, D. (1990). Populism and democratic thought in the Canadian prairies, 1910-1945. Toronto: University of Toronto Press.

Laycock, D. (1994). Reforming Canadian democracy? Institutions and ideology in the reform party project. Canadian Journal of Political Science, 27(2), 213-247.

Liberty moves north: Canada's example to the world. (2016, October 29). The Economist. Retrieved from https://www.economist.com/leaders/2016/10/29/ liberty-moves-north

Malloy, J. (2017). Political parties and the party system in Ontario. In C. N. Collier \& J. Malloy (Eds.), The politics of Ontario (pp. 192-208). Toronto: University of Toronto Press.

Marche, S. (2018, March 22). Will Canada elect a tin-pot northern Trump? The New York Times. Retrieved from https://www.nytimes.com/2018/03/ 22/opinion/doug-ford-populism-canada-trump.html

Martin, G. R. (1995). The rise and fall of the New Brunswick CoR Party, 1988-1995. Canadian Parliamentary Review, 18(3), 19-22.

Moffitt, B. (2016). The global rise of populism: Performance, political style, and representation. Palo Alto, CA: Stanford University Press.

Mudde, C. (2004). The populist zeitgeist. Government and Opposition, 39(4), 541-563.

Mudde, C. (2007). Populist radical right parties in Europe. Cambridge: Cambridge University Press.

Mudde, C., \& Kaltwasser, C. R. (2011). Voices of the peoples: Populism in Europe and Latin America compared (Working Paper No. 378). Notre Dame, IN: Kellogg Institute.

Norris, P. (2005). Radical right: Voters and parties in the electoral market. Cambridge, MA: Cambridge University Press.

Porter, C. (2018, June 2). Will a Canadian Donald Trump become Ontario's leader? The New York Times. Retrieved from https://www.nytimes.com/2018/06/ 02/world/canada/doug-ford-ontario.html

Powers, L. (2018, April 18). Kathleen Wynne compares Doug Ford to Donald Trump, saying he 'traffics in smears and lies.' $C B C$ News. Retrieved from https://www.cbc.ca/news/canada/toronto/wynneford-trump-ontario-election-campaign-1.4624638 
Progressive Conservative Party of Ontario. (2018). For the people: A plan for Ontario. Progressive Conservative Party of Ontario. Retrieved from https://www. ontariopc.ca/plan_for_the_people

Sawer, M., \& Laycock, D. (2009). Down with elites and up with inequality: Market populism in Australia and Canada. Commonwealth \& Comparative Politics, 47(2), 133-150.

Silver, D., Taylor, Z., \& Calderón-Figueroa, F. (2019). Populism in the city: The case of Ford Nation. International Journal of Politics, Culture, and Society. Advance online publication. https://doi.org/10.1007/ s10767-018-9310-1

Snow, D., \& Moffitt, B. (2012). Straddling the divide: Mainstream populism and conservatism in Howard's Australia and Harper's Canada. Commonwealth \& Comparative Politics, 50(3), 271-292.

Taggart, P. (2000). Populism. Philadelphia, PA: Open University Publishing.

Thomas, M. P., \& Tufts, S. (2016). Austerity, right pop- ulism, and the crisis of labour in Canada. Antipode, 48(1), 212-230.

van Dijk, T. A. (1995). Discourse analysis as ideology analysis. In C. Schäffner \& A. Wenden (Eds.), Language and peace (pp. 17-33). Aldershot: Dartmouth Publishing.

Wiseman, N. (2006). Provincial political cultures. In Christopher Dunn (Ed.), Provinces: Canadian provincial politics (2nd ed., pp. 21-56). Peterborough: Broadview Press.

Woolstencroft, P. (1997). Reclaiming the 'pink palace': The Progressive Conservative Party comes in from the cold. In G. White (Ed.), The government and politics of Ontario (5th ed., pp. 365-401). Toronto: University of Toronto Press.

Woolstencroft, P. (2016). Political culture in Ontario: New and old. In C. N. Collier \& J. Malloy (Eds.), The politics of Ontario (pp. 58-80). Toronto: University of Toronto Press.

\section{About the Author}

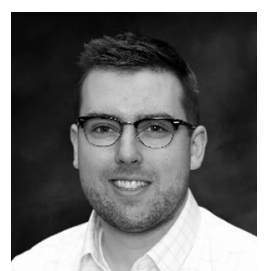

Brian Budd is a PhD Candidate in the Department of Political Science at the University of Guelph located in Ontario, Canada. His research interests include the contemporary and historical role of right-wing populism in Canadian politics, with an emphasis on political leadership, ideology, and discourse. His published work can be found in the edited collection, Populism and World Politics: Exploring Inter- and Transnational Dimensions, as well as in the Journal of Parliamentary and Political Law, The International Indigenous Policy Journal, and the Journal of Native Studies. 